\title{
The View from "White Man's Bay": The Captain John Matthews Papers on Sierra Leone at the Firestone Memorial Library, Princeton University
}

\author{
Devin Leigh (1)
}

\begin{abstract}
In 2017, the Department of Rare Books and Special Collections at the Firestone Memorial Library, Princeton University, acquired the papers of a British enslaver who operated in the region of greater Sierra Leone during the lateeighteenth century. This article offers an introduction to these papers for potential researchers. Focusing on two journals that cover Matthews's time in the region between 1785 and 1787, it suggests three topics for which the collection might be of value to scholars of early-modern West Africa. These three topics are the local workings of the transatlantic slave trade in greater Sierra Leone; the production of European knowledge about Africa and Africans; and the history of the region immediately preceding the settlement of Freetown. In addition, this article includes four images of Sierra Leone. Black and white versions of these images were printed in 1791 , but the watercolors are reproduced here for the first time.
\end{abstract}

Résumé: En 2017, le Département des livres rares et des collections spéciales de la Firestone Memorial Library (Université de Princeton) a acquis les papiers d'un marchand d'esclaves britannique qui opérait dans la région de la grande Sierra Leone à la fin du XVIIIe siècle. Cet article propose une introduction à ces documents pour les chercheurs potentiels. En se concentrant sur deux carnets qui couvrent les années

History in Africa, Volume 48 (2021), pp. 383-396

Devin Leigh is a PhD Candidate and Teaching Assistant at the University of California at Davis. His research focuses on the British Isles, West Africa, and the West Indies in the eighteenth century. E-mail: dtleigh@ucdavis.edu

(C) The Author(s), 2021. Published by Cambridge University Press on behalf of the African Studies Association. This is an Open Access article, distributed under the terms of the Creative Commons Attribution licence (http:/ / creativecommons.org/ licenses/by/4.0/), which permits unrestricted re-use, distribution, and reproduction in any medium, provided the original work is properly cited.

doi:10.1017/hia.2021.2

*This article was reviewed internally by the History in Africa editorial team. 
1785 et 1787, une période où Matthews était dans la région, cet article suggère trois sujets pour lesquels la collection pourrait être utile aux chercheurs de l'Afrique de l'Ouest moderne. Ces trois thèmes sont tout d'abord les rouages locaux de la traite transatlantique des esclaves dans la grande Sierra Leone, ensuite la production de connaissances européennes sur l'Afrique et les Africains, et enfin l'histoire de la région précédant juste la colonisation de Freetown. Qui plus est, cet article comprend quatre aquarelles de la Sierra Leone. Des versions en noir et blanc de ces images ont été imprimées en 1791, mais les aquarelles sont reproduites ici pour la première fois en couleur.

In 2017, the Department of Rare Books and Special Collections at the Firestone Memorial Library, Princeton University, acquired a collection of papers related to John Matthews that was previously unknown to historians. ${ }^{1}$ Matthews was a British naval officer and enslaver in the late-eighteenth century with close ties to the region of greater Sierra Leone, which he defined as extending from roughly the Rio Nuñez in the present-day nation of Guinée-Conakry, to Cape St. Ann in the south of the present-day nation of Sierra Leone. ${ }^{2}$ Kelly Bolding, a project archivist at Princeton, and Don Skemer, a manuscripts curator, have already summarized the broad contents of the "Captain John Matthews Papers" for potential researchers. ${ }^{3}$ The following archives report will focus on two of the four logbooks included in the collection. These books cover Matthews's employment as co-agent for a London-based slaving firm, named Samuel Hartley and Company, between

1 The author would like to thank the following people: John Smolenski, Lorelle Semley, Robin Law, John Thornton, Deirdre Coleman, Emma Sarconi, Jeremy Till, Kathryn Reed-Smith, the staff of the Harvey S. Firestone Memorial Library at Princeton University, the staff and faculty of the UC Davis History Department and UC Davis Graduate Studies, the editors and staff at Cambridge University Press, the anonymous reviewers who read this piece, and the editors and staff at History in Africa.

2 The term "Sierra Leone" was used inconsistently by European writers throughout the early-modern era. See Paul Edward Hedley Hair, "The Spelling and Connotation of the Toponym 'Sierra Leone' since 1461, 'Sierra Leone Studies 18 (1966), 4358. For Matthews's definition of this region, see John Matthews, "Chart of Part of the Coast of Africa, from Cape St. Ann, to the River Rionoones," in A Voyage to the River Sierra-Leone, on the Coast of Africa (London: B. White and Sons, 1788; 2nd Edn, 1791), 1.

3 Kelly Bolding, "Finding Aid for the Captain John Matthews Papers," Department of Rare Books and Special Collections at Princeton University Library, (24 August 2017), https://findingaids.princeton.edu/collections/C1575/\#sum mary, (accessed 20 March 2020); Don Skemer, "Eyewitness to the Slave Trade," RBSC Manuscripts Division News (7 August 2017), https://blogs.princeton.edu/manu scripts /2017/08/07/eye witness-to-the-african-slave-trade/, (accessed 19 July 2019). These summaries were based partly upon the following description of the materials: Anonymous, "Advertisement for John Matthews's Archive of Four Ships's Journals and Related Papers," Sotheby's Auction House (17 July 2017), http://www.sothebys.com/ en/auctions/ecatalogue/2017/english-literature-117404/lot.7.html, (accessed 21 May 2020). It is not clear who owned these papers prior to 2017. 
April of 1785 and May of $1787 .{ }^{4}$ Matthews's operations were based out of a factory that was situated in "White Man's Bay," an inlet on the northern coast of the Sierra Leone Peninsula. ${ }^{5}$ Matthews represented this coast himself in a series of watercolor images that he produced at the time of his residency (see Figure 1). More specifically, this report will suggest three topics for which these journals might be of value to scholars of early-modern West Africa. These topics are the local workings of the transatlantic slave trade in greater Sierra Leone; the production of European knowledge about Africa and Africans; and the history of the region in the years preceding the settlement of Freetown.

First, Matthews's logbooks are valuable because they provide insight into the local workings of the transatlantic slave trade in a coastal region that was defined by neither the presence of a centralized African state or an official European firm. Scholars of the slave trade in precolonial West Africa have long recognized, in the words of the historian Toby Green, that "There was not one Atlantic slave trade, but [instead] many trades wreaking many different effects...." ${ }^{6}$ In comparison to some other areas of the West African coast where European enslavers operated-like present-day Senegal, The Gambia, Ghana, Benín, and Congo-Angola-there were no large European forts and few chartered companies operating in the region of Sierra Leone. There were also no large African states or kingdoms in direct contact with European traders, even though the inland state of Fuuta Jalon did exercise a great influence over the coastal slave trade. ${ }^{7}$ Also, unlike in southeastern

4 Princeton University Libraries, Firestone Memorial Library, Princeton, USA, Manuscripts Division, Special Collections, Captain John Matthews Papers, C1575, "Journal One: 28 April 1785 - 15 May 1787" and "Journal Two: 1 April 1786 31 March 1787." John Matthews and William Harrison are described as the co-agents of Samuel Hartley and Company of London in several drafts of a contract with local traders from the Bay of Sherbro. These drafts can be found at the back of Journal One.

5 For a contemporary map that shows the location of "White Man's Bay," see National Archives, Kew, UK, MPG 1/1132/1, Anonymous, Plan of Sierra Leone and the Parts Adjacent (London: James Phillips, 1794). Although the inlet is not labeled, it lies between "Pirate's Bay" and "Jimmy's Town." Matthews's factory was "nearly adjoining" the town at the bottom of the inlet, called Ya Ma Cooba's town. See Matthews, A Voyage, 2nd Edn. (1791), v. It is not clear when the name "White Man's Bay" was first applied to this inlet; however, it appears to have been used regularly by at least the mid-eighteenth century. For an earlier example of its usage, see John Newton, The Journal of a Slave Trader (John Newton), 1750-1754, with Newton's Thoughts upon the African Slave Trade, edited by Bernard Martin and Mark Spurrell (London: Epworth Press, 1962), 66.

6 Toby Green, The Rise of the Trans-Atlantic Slave Trade in Western Africa, 1300-1589 (Cambridge: Cambridge University Press, 2012), 14. For an overview of West Africa during this period, see Toby Green, A Fistful of Shells: West Africa from the Rise of the Slave Trade to the Age of Revolution (Chicago: University of Chicago Press, 2019).

7 For some studies that discuss Fuuta Jalon and its effects on greater Sierra Leone in the late-eighteenth century, see Boubacar Barry, Senegambia and the Atlantic Slave Trade (Cambridge: Cambridge University Press, 1998); Bruce L. Mouser, "Rebellion, 
Figure 1. Original watercolor image of "A View of the entrance into Sierra-leone River," Captain John Matthews Papers, Manuscripts Division, Special Collections, Firestone Memorial Library, Princeton University Libraries, C1575, Box 2, Folder 4. In the second edition of his travelogue, A Voyage to the River Sierra-Leone, Matthews published a series of black and white sketches that portrayed the region. The image shown here is one of four original watercolors that have survived in the Captain John Matthews Papers. It depicts the entrance to the Sierra Leone River from the deck of a ship offshore in the Atlantic Ocean. Courtesy of Princeton University Library.

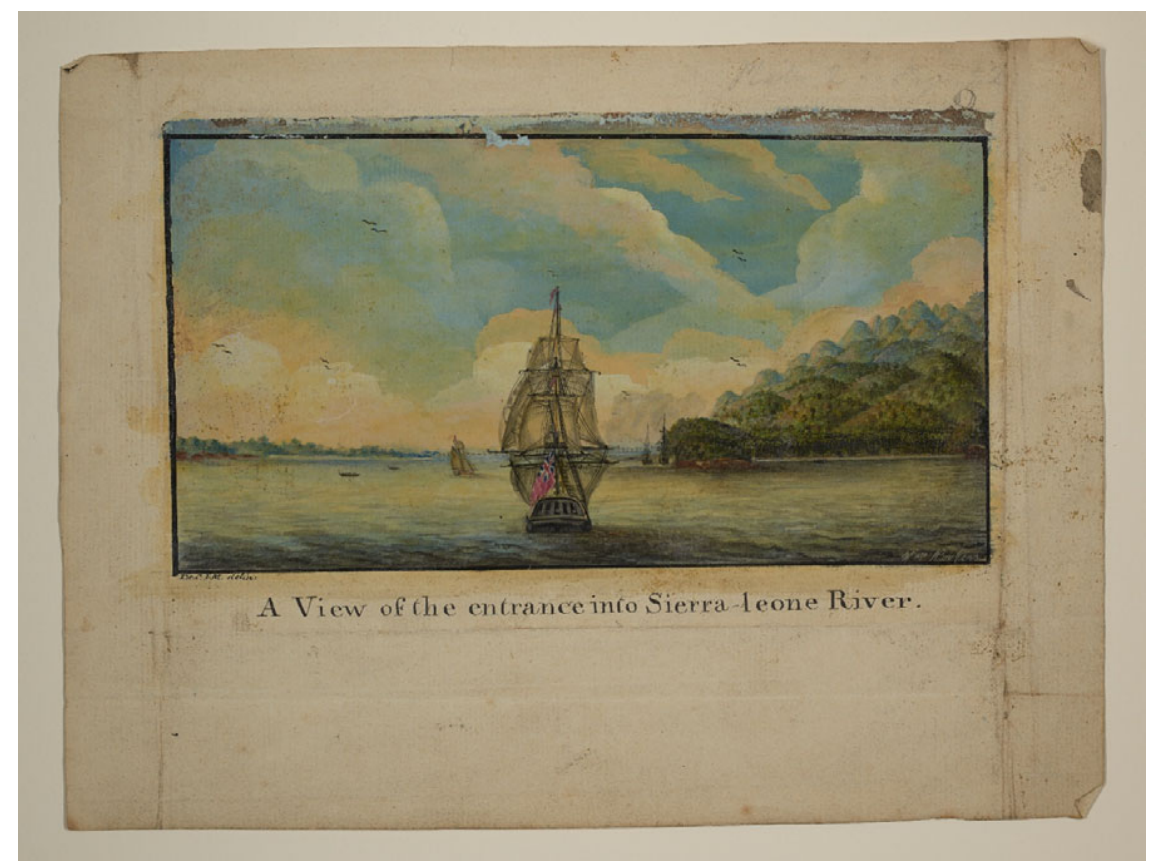

Nigeria, white traders were allowed to maintain factories on the coast. ${ }^{8}$ Like his contemporaries, Matthews negotiated with small host communities in a

Marronage, and Jihād: Strategies of Resistance to Slavery on the Sierra Leone Coast, 1783-1796," The Journal of African History 48-1 (2007), 27-44; Bronislaw Nowak, "The Slave Rebellion in Sierra Leone in 1785-1796," Hemispheres 3 (1986), 151-169; and Paul E. Lovejoy, Jihād in West Africa during the Age of Revolutions (Athens: Ohio University Press, 2016). For an early European written account of Timbo, the capital of Fuuta Jalon, see James Watt, Journal of James Watt: Expedition to Timbo, Capital of the Fula Empire in 1794, edited by Bruce L. Mouser (Madison: University of Wisconsin Madison, 1994).

${ }^{8}$ For an introduction to the transatlantic slave trade in southeastern Nigeria during this period, see G. Ugo Nwokeji, The Slave Trade and Culture in the Bight of Biafra (Cambridge: Cambridge University Press, 2010). 
"landlord-stranger" relationship, in which he paid ground rent and customs duties for protected residency and permission to conduct trade by "boating" up and down the shore. ${ }^{9}$ In the process, he drew upon shared traditions of Afro-European commerce that went back to the fifteenth century, and that were rooted in cultures of ancestry, marriage, language, migration, and credit. ${ }^{10}$ He married a local woman as a "country wife" and had a son with her; he relied upon skilled and gendered Temne labor to run his business; and he engaged in long-tested customs of Afro-European commerce that were meant to secure trust and credit. ${ }^{11} \mathrm{He}$ also interacted with a diversity of sovereign local communities and a constellation of European and mixed-race residents who functioned as local leaders. He depicted the home of one of these leaders, the Anglo-African trader James Cleveland, in one of his drawings (see Figure 2).

Second, Matthews's logbooks are valuable because they offer an opportunity to examine the production of European knowledge about Africa and Africans. Scholars have found a number of logbooks by European enslavers who operated off the coast of greater Sierra Leone, and they have sometimes been able to see how white enslavers constructed public knowledge of West Africa in the early-modern period over a series of revised texts. ${ }^{12}$ Nonetheless,

9 This practice of "boating" in greater Sierra Leone is described in the following contemporary source: Alexander Falconbridge, An Account of the Slave Trade on the Coast of Africa (London: James Phillips, 1788), 18, 48. For an introduction to this "landlord-stranger" relationship, see Bruce L. Mouser, "Landlords-Strangers: A Process of Accommodation and Assimilation," The International Journal of African Historical Studies 8-3 (1975), 425-440; and George E. Brooks, Eurafricans in Western Africa: Commerce, Social Status, Gender, and Religious Observance from the Sixteenth to the Eighteenth Century (Athens OH: Ohio University Press, 2003), esp. 28-29, 49-50, 71-72.

${ }^{10}$ For an introduction to interracial marriage and trade in West Africa during the early-modern period, see Pernille Ipsen, Daughters of the Trade: Atlantic Slavers and Interracial Marriage on the Gold Coast (Philadelphia: University of Pennsylvania Press, 2016).

11 For mention of Matthews's son born in Sierra Leone in 1786, see National Archives, Kew, UK, PROB 11/1308/122, "Will of John Matthews, Captain in the Royal Navy of Chester, Cheshire," 15 June 1798. For a similar example of establishing trust and credit in the transatlantic slave trade without the presence of a centralized African state, see Paul E. Lovejoy and David Richardson, "Trust, Pawnship, and Atlantic History: The Institutional Foundations of the Old Calabar Slave Trade," The American Historical Review 104-2 (1999), 333-355. For context on gender and labor among the Koya Temne residents of the Sierra Leone Peninsula, see Joseph J. Bangura, The Temne of Sierra Leone: African Agency in the Making of a British Colony (Cambridge: Cambridge University Press, 2017).

12 For a few examples of the former, see Bruce L. Mouser (ed.), A Slaving Voyage to Africa and Jamaica: The Log of the Sandown, 1793-1794 (Bloomington: Indiana University Press, 2002); Nicholas Owen, Journal of a Slave-Dealer, edited by Eveline Martin (New York: Houghton Mifflin Company, 1930); and Newton, Journal of a Slave Trader, edited by Martin and Spurrell. For an example of the latter, see the case of 
Figure 2. Original watercolor image of "A View of the East end of the Island of Bananas," Captain John Matthews Papers, Manuscripts Division, Special Collections, Firestone Memorial Library, Princeton University Libraries, C1575, Box 2, Folder 1. This image is the second of four watercolor drawings of Sierra Leone included in the Captain John Matthews Papers. It depicts the Banana Islands off the southern shore of the Sierra Leone Peninsula. Matthews regularly sailed to the Banana Islands to conduct business with its resident, a mixed-race trader by the name of James Cleveland. Cleveland's home is barely visible here amongst the cluster of trees in the middle of the picture. Matthews later described this home as being "furnished in the English stile, but built...in the country manner." Courtesy of Princeton University Library.



William Snelgrave, who produced a diary, manuscript, and then final draft of a history of Dahomey's coastal wars in the 1720s. For the diary, see Neal Polhemus, "A Dialogue with King Agaja: William Snelgrave's 1727 Ardra Diary and the Contours of Dahomian-European Commercial Exchange," History in Africa 43 (2016), 29-62. For the manuscript, see Robin Law, "The Original Manuscript Version of Snelgrave's 'New Account of Some Parts of Guinea,'” History in Africa 17 (1990), 367-372; and, for the final version, see William Snelgrave, A New Account of Some Parts of Guinea and the Slave Trade (London: James, John, and Paul Knapton, 1734). For a narrative history of the transatlantic slave trade that is based upon an enslaver's logbook, see Robert Harms, The Diligent: A Voyage through the Worlds of the Slave Trade (New York: Basic Books, 2002). 
it is rare to uncover logbooks by an enslaver who produced so much other contemporary written material about the area in which he operated. ${ }^{13}$ Matthews was part of a generation of enslavers who produced proslavery work on Africa and Africans during the British government's investigation into the economics and morality of the transatlantic slave trade. After returning from Sierra Leone in 1788, he worked as a delegate for the antiabolitionist lobby. ${ }^{14}$ He testified against the abolitionists before the Privy Council and the House of Commons; he protested abolition in private letters to the chair of the investigation; and, finally, he published a proslavery travel book about Sierra Leone, entitled A Voyage to the River Sierra-Leone ${ }^{15}$ Historians can now compare Matthews's logbooks with his testimonies and his travel account in order to better see how Europeans produced public knowledge of a region like Sierra Leone across different textual genres and for a distinct political agenda. ${ }^{16}$ They can study in a more particular way which

13 An exception here would be the case of the abolitionist John Newton. For example, Newton wrote journals of his time as an enslaver in Sierra Leone during the 1750s. He also produced an autobiography in 1764 and a pamphlet in 1788, and gave testimony to the Privy Council and the House of Commons in 1789 and 1790. For a list of these sources, see Martin and Spurrell's introduction to Newton, The Journal of a Slave Trader, ix-xvii.

14 The story of Matthews's delegation is told in Frank E. Sanderson, "The Liverpool Delegates and Sir William Dolben's Bill," Transactions of the Historic Society of Lancashire and Cheshire 124 (1972), 57-84. Although it is not clear when Matthews arrived in England, it was by at least 20 February 1788. See Matthews, A Voyage, 160.

15 For the text's initial publication, see Anonymous, "Advertisement for the Publication of John Matthews's A Voyage to the River Sierra-Leone," Gazetteer and New Daily Advertiser, 3 April 1788. For an annotated discussion of the travel account, see Robin Law (ed.), The British Transatlantic Slave Trade, Volume 1, The Operation of the Slave Trade in Africa (London: Pickering \& Chatto, 2003), 374-378. For the work's contemporary influence on British abolitionists and colonizationists, see Suzanne Schwarz, "'A Just and Honourable Commerce': Abolitionist Experimentation in Sierra Leone in the Late Eighteenth and Early Nineteenth Centuries," African Economic History 45-1 (2017), 1-45. For Matthews's letters to the chairman of the Privy Council's investigation, see British Library, London, UK, Lord Liverpool Papers, Add. MS 38416, Letters of John Matthews to Lord Hawkesbury, 20 March 1788 and 22 March 1789, ff. 56r and 232r-233v; and National Archives, Kew, UK, BT 6/11, John Matthews, "Observations on the Conduct of Mulatto and Black African Children," 20 August 1788, no page numbers.

16 National Archives, Kew, UK, BT 6/9, Privy Council Testimony of John Matthews, 4 March 1788, 239-265; and "House of Commons Testimony of John Matthews," 3 June 1788, in Sheila Lambert (ed.), House of Commons Sessional Papers of the Eighteenth Century, 144 Vols. (Wilmington, DE: Scholarly Resources, 1975), 68: 19-27. For a guide to the House of Commons testimonies, see Paul E. Lovejoy and Vanessa S. Oliveira, "An Index to the Slavery and Slave Trade Enquiry: The British Parliamentary House of Commons Sessional Papers, 1788-1792," History in Africa 40 (2013), 193-255. Matthews's Privy Council testimony was reproduced in the 
Figure 3. Original watercolor image of "A View of the South side of Sierra-leone River from... Leopards Island," Captain John Matthews Papers, Manuscripts Division, Special Collections, Firestone Memorial Library, Princeton University Libraries, C1575, Box 2, Folder 2. The third of these four watercolor images depicts the Sierra Leone Peninsula from across the river. The late-eighteenth century was a period of growing European interest in Sierra Leone, due largely to the mission of British abolitionists to establish a colony there based upon free labor. In both his testimony and his travelogue, Matthews positioned himself as an expert on the region. The dark clouds at the top of this picture almost certainly depict the Harmattan, a seasonal wind in West Africa that Matthews described as a thick smoke. The deforested slope of the mountain in the foreground was meant to show tracts of land that had been previously cultivated or newly cleared for agriculture. Courtesy of Princeton University Library.

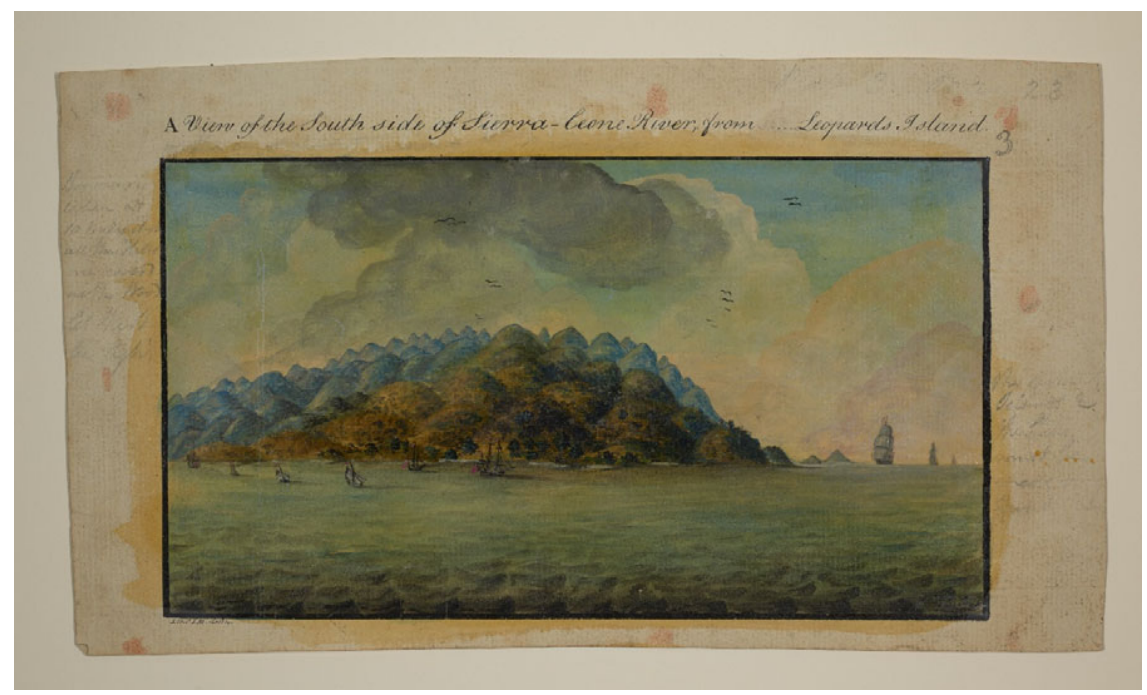

aspects of life in West Africa enslavers chose to silence and which aspects they chose to emphasize for their own political purposes. To mention just one example here, Matthews represented Sierra Leone in both his testimony and his travelogue as a picturesque landscape of natural abundance and scientific curiosity. This representation can be seen in the instructive nature of the images that he produced (see Figure 3). By doing so, he downplayed the real threat that the climate posed for any potential migrants. It is only in Matthews's unpublished logs that we learn just how sick the free and enslaved

following volume: Board of Trade, Report of the Lords of the Committee of Council Appointed to the Consideration of All Matters Relating to Trade and Foreign Plantations (London: British Government Printing Office, 1789). For manuscript versions of the House of Commons testimonies, see National Archives, Kew, UK, ZHC 1/82. 
people at his factory became. Matthews himself almost died after he became "full ill" for two weeks in the summer of $1786 .{ }^{17}$

Finally, Matthews's logbooks are valuable because they may comprise the most intimate look at life on the north coast of the Sierra Leone Peninsula immediately preceding the founding of the Sierra Leone colony. Britain established its first permanent settler colony in West Africa in 1787, when abolitionists resettled approximately 400 impoverished black residents of London on the eastern side of what is today Kroo Bay, Freetown. ${ }^{18}$ This first cohort was followed up another five years later by a second settlement in the same location, this one comprised of roughly 1,000 black settlers from the British colony of Nova Scotia. ${ }^{19}$ Matthews's factory was situated only two miles to the west of this spot, and his journals cover the two years leading up to the first cohort's arrival. This means that he was closer to Freetown, both temporally and geographically, than the other contemporary writers whom we know about, including Nicholas Owen, John Newton, and Henry Smeathman. ${ }^{20}$ In fact, Matthews actually documented the landing of the settlers in the last entry of his log and included a black and white drawing of the event in

17 On Matthews's illness, see C1575, Journal Two, Entries from 22 June 1786 5 July 1786, no pages. For an example of his servants dying by sickness, see C1575, Journal Two, Entry from 8 July 1786, no pages.

18 The story of this settlement is told in the following study: Stephen J. Braidwood, Black Poor and White Philanthropists: London's Blacks and the Foundation of the Sierra Leone Settlement, 1786-1791 (Liverpool: Liverpool University Press, 2011). For narratives of the founding of the 1787 colony, see Christopher Fyfe, A History of Sierra Leone (Oxford: Oxford University Press, 1962), 13-37; and John Peterson, Province of Freedom: A History of Sierra Leone, 1787-1870 (London: Faber \& Faber, 1969), 17-44. For studies of the Sierra Leone region to 1787, see Alexander Peter Kup, A History of Sierra Leone, 1400-1787 (Cambridge: Cambridge University Press, 1961); Paul Edward Hedley Hair, "Christian Influences in Sierra Leone before 1787," Journal of Religion in Africa 16-1 (1996), 3-14; and Robin Law, "Before 1787: The First 325 Years of Afro-European Interactions in Sierra Leone," in Schwarz, Suzanne and Lovejoy, Paul E. (eds.), Sierra Leone Past and Present (Trenton, NJ: Africa World Press, forthcoming). Although Britain had an earlier colony in Africa at Senegambia, this was short lived and not a settler society. The British Senegambia colony lasted from 1765-83 and produced few settlers.

${ }^{19}$ For an introduction to the experiences of these settlers, see James W. St. G. Walker, The Black Loyalists: The Search for a Promised Land in Nova Scotia and Sierra Leone 1783-1870 (London: Longman, 1976).

${ }^{20}$ Owen kept a journal in greater Sierra Leone from about 1754-9, while he was based in the Bay of Sherbro. Newton kept a journal of his voyages to Sierra Leone from about 1750-4 and had previously resided for a year on the Plantain Islands. Smeathman resided on the Banana Islands from about 1771-5. For his history, see Deirdre Coleman, Henry Smeathman, the Flycatcher: Natural History, Slavery, and Empire in the Late Eighteenth Century (Liverpool: Liverpool University Press, 2018). The Banana Islands are located off the southwestern tip of the Sierra Leone Peninsula, and the Plantain Islands are located at the mouth of the Sherbro River. 
Figure 4. Original watercolor image of "A View of Sierra-Leone River, from St. George's Hill, where the Free Black settlement was made in the year 1787," Captain John Matthews Papers, Manuscripts Division, Special Collections, Firestone Memorial Library, Princeton University Libraries, C1575, Box 2, Folder 3. The final image in this series of four watercolors depicts the arrival of the free black setters in 1787. In the final entry of his journal, Matthews writes that he returned to his factory from the Bay of Sherbro at 3:00 p.m. on Tuesday, 15 May, and found the settlers' transport ships laying at anchor. This drawing was probably not created by Matthews himself, although it was first published in the second edition of his travelogue. Unlike that black and white print, this color version represents a few of the black settlers. They can be seen walking amongst the buildings and on the road that leads to the shore. Courtesy of Princeton University Library.

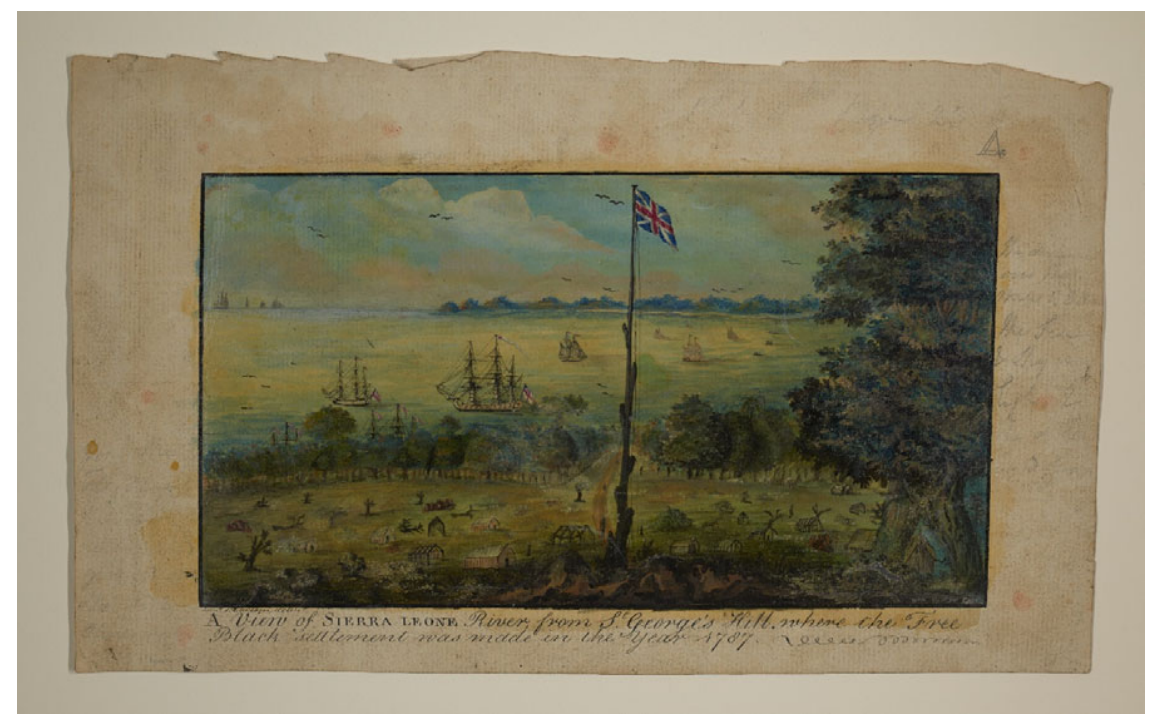

the second edition of $A$ Voyage. ${ }^{21}$ The original watercolor of that drawing is included here (see Figure 4). To date, this drawing remains the only historical image that we have of the initial settlement. It portrays the black settlers erecting the colony's first wood frame houses in an area of cleared land at the base of what is today Tower Hill.

21 C1575, Journal One, Entry from 15 May 1787, no pages. Anonymous, "A View of Sierra-Leone River, from St. George's Hill, where the Free Black Settlement was made in the Year 1787," Schomburg Center for Research in Black Culture (2019), https:/ / digitalcollections.nypl.org/items/510d47da-6fba-a3d9-e040-e00a18064a99, (accessed 3 November 2020). This image was originally published in Matthews, $A$ Voyage, 2nd Edn. (1791), 22-23. 
To end with a specific example about the Sierra Leone colony, the Captain John Matthews Papers can help us better understand the upheaval that the first black settlers experienced. On the eve of colonization, black abolitionists in London, such as Ottobah Cugoano, recognized the danger that migration to Sierra Leone posed for these potential settlers. Cugoano questioned in his pamphlet, titled Thoughts and Sentiments, whether a "free colony" could really survive "nearly on the spot" where enslavers operated. ${ }^{22}$ His words proved to be prescient, as the first settlement was burned to the ground by the local Temne leader, King Jimmy, just a couple of years later, in December of 1789. Matthews's logbooks allow us to see the instability that prevailed in the years before these settlers arrived. For example, they show villagers abandoning their homes in the Bay of Sherbro during wartime; captives and pawns fleeing Matthews and his patrons at "White Man's Bay" for fear of being transported; and locals plotting to murder Matthews just as one of his predecessors, a European slave trader named John Tittle, was killed by locals in the 1770 s. ${ }^{23}$ In these ways and more, the Captain John Matthews Papers at Princeton University can serve as a valuable resource for scholars working on the history of early-modern Sierra Leone and West Africa.

\section{References}

Anonymous, “Advertisement for John Matthews's Archive of Four Ships's Journals and Related Papers,” Sotheby's Auction House (17 July 2017), http:/ / www.sothebys.com/ en/auctions/ecatalogue/2017/english-literature-117404/lot.7.html, (accessed 21 May 2020).

Anonymous, “Advertisement for the Publication of John Matthews's A Voyage to the River Sierra-Leone," Gazetteer and New Daily Advertiser, 3 April 1788.

Anonymous, "A View of Sierra-Leone River, from St. George's Hill, where the Free Black Settlement was made in the Year 1787," Schomburg Center for Research in Black Culture (2019), https:/ / digitalcollections.nypl.org/items/510d47da-6fbaa3d9-e040-e00a18064a99, (accessed 3 November 2020).

22 Ottobah Cugoano, Thoughts and Sentiments on the Evil and Wicked Traffic of the Slavery and Commerce of the Human Species (London: N.P., 1787), 138-142 here 142.

23 Although his name is not used, Tittle's story is told in Matthews, A Voyage, 3-4. His name is mentioned, however, in C1575, Journal One, Entry from 15 September 1785, no page. For context on John Tittle, see Coleman, Henry Smeathman, 71-72. Apparently, the story of his death was well-known in the region. For a contemporary account, see Anna Maria Falconbridge, Two Voyages to Sierra Leone, During the Years 1791 -2-3 (London: For the Author, 1794), 27-30. Matthews says that Tittle died about fourteen years before his arrival in 1785, while Coleman says that he was killed in 1776. This discrepancy is not surprising, as it was common for eighteenth-century authors like Matthews to misremember dates. For Tittle's slave-trading in the region, see Various, "John Tittle's Voyages," Voyages: The Trans-Atlantic Slave Trade Database (2016), https://www.slavevoyages.org/voyage/database, (accessed 3 November 2020), Nos. 91076, 91303, 91422, 91559, 91495, and 91816. 
Bangura, Joseph J., The Temne of Sierra Leone: African Agency in the Making of a British Colony (Cambridge: Cambridge University Press, 2017).

Barry, Boubacar, Senegambia and the Atlantic Slave Trade (Cambridge: Cambridge University Press, 1998).

Board of Trade, Report of the Lords of the Committee of Council Appointed to the Consideration of All Matters Relating to Trade and Foreign Plantations (London: British Government Printing Office, 1789).

Bolding, Kelly, "Finding Aid for the Captain John Matthews Papers," Department of Rare Books and Special Collections at Princeton University Library (24 August 2017), https:/ / findingaids.princeton.edu/collections/C1575/\#summary, (accessed 20 March 2020).

Braidwood, Stephen J., Black Poor and White Philanthropists: London's Blacks and the Foundation of the Sierra Leone Settlement, 1786-1791 (Liverpool: Liverpool University Press, 2011).

British Library, London, UK, Lord Liverpool Papers, Add. MS 38416, Letters of John Matthews to Lord Hawkesbury, 20 March 1788 and 22 March 1789, ff. 56r and 232r-233v.

Brooks, George E., Eurafricans in Western Africa: Commerce, Social Status, Gender, and Religious Observance from the Sixteenth to the Eighteenth Century (Athens: Ohio University Press, 2003).

Coleman, Deirdre, Henry Smeathman, the Flycatcher: Natural History, Slavery, and Empire in the Late Eighteenth Century (Liverpool: Liverpool University Press, 2018).

Cugoano, Ottobah, Thoughts and Sentiments on the Evil and Wicked Traffic of the Slavery and Commerce of the Human Species (London: N.P., 1787).

Falconbridge, Alexander, An Account of the Slave Trade on the Coast of Africa (London: James Phillips, 1788).

Falconbridge, Anna Maria, Two Voyages to Sierra Leone, During the Years 1791-2-3 (London: For the Author, 1794).

Fyfe, Christopher, A History of Sierra Leone (Oxford: Oxford University Press, 1962).

Green, Toby, The Rise of the Trans-Atlantic Slave Trade in Western Africa, 1300-1589 (Cambridge: Cambridge University Press, 2012).

— A Fistful of Shells: West Africa from the Rise of the Slave Trade to the Age of Revolution (Chicago: University of Chicago Press, 2019).

Hair, Paul Edward Hedley, "The Spelling and Connotation of the Toponym 'Sierra Leone' since 1461,” Sierra Leone Studies 18 (1966), 43-58.

—, "Christian Influences in Sierra Leone before 1787," Journal of Religion in Africa 16-1 (1996), 3-14.

Harms, Robert, The Diligent: A Voyage through the Worlds of the Slave Trade (New York: Basic Books, 2002).

Ipsen, Pernille, Daughters of the Trade: Atlantic Slavers and Interracial Marriage on the Gold Coast (Philadelphia: University of Pennsylvania Press, 2016).

Kup, Alexander Peter, A History of Sierra Leone, 1400-1787 (Cambridge: Cambridge University Press, 1961).

Lambert, Sheila (ed.), House of Commons Sessional Papers of the Eighteenth Century, 144 Vols. (Wilmington DE: Scholarly Resources, 1975).

Law, Robin, “The Original Manuscript Version of Snelgrave's 'New Account of Some Parts of Guinea," History in Africa 17 (1990), 367-372.

- (ed.), The British Transatlantic Slave Trade, Volume 1, The Operation of the Slave Trade in Africa (London: Pickering \& Chatto, 2003). 
—, "Before 1787: The First 325 Years of Afro-European Interactions in Sierra Leone," in Schwarz, Suzanne and Lovejoy, Paul E. (eds.), Sierra Leone Past and Present (Trenton, NJ: Africa World Press, forthcoming).

Lovejoy, Paul E. and David Richardson, "Trust, Pawnship, and Atlantic History: The Institutional Foundations of the Old Calabar Slave Trade," The American Historical Review 104-2 (1999), 333-355.

Lovejoy, Paul E. and Vanessa S. Oliveira, "An Index to the Slavery and Slave Trade Enquiry: The British Parliamentary House of Commons Sessional Papers, 17881792," History in Africa 40 (2013), 193-255.

Lovejoy, Paul E., Jihād in West Africa during the Age of Revolutions (Athens: Ohio University Press, 2016).

Matthews, John, A Voyage to the River Sierra-Leone, on the Coast of Africa (London: B. White and Sons, 1788; 2nd Edn., 1791).

Mouser, Bruce L., "Landlords-Strangers: A Process of Accommodation and Assimilation," The International Journal of African Historical Studies 8-3 (1975), 425-440.

(ed.), A Slaving Voyage to Africa and Jamaica: The Log of the Sandown, 1793-1794 (Bloomington: Indiana University Press, 2002).

—, "Rebellion, Marronage, and Jihād: Strategies of Resistance to Slavery on the Sierra Leone Coast, 1783-1796," The Journal of African History 48-1 (2007), 27-44.

National Archives, Kew, UK, MPG 1/1132/1, Anonymous, Plan of Sierra Leone and the Parts Adjacent (London: James Phillips, 1794).

National Archives, Kew, UK, PROB 11/1308/122, "Will of John Matthews, Captain in the Royal Navy of Chester, Cheshire," 15 June 1798.

National Archives, Kew, UK, BT 6/11, John Matthews, "Observations on the Conduct of Mulatto and Black African Children,” 20 August 1788.

National Archives, Kew, UK, BT 6/9, Privy Council Testimony of John Matthews, 4 March 1788.

National Archives, Kew, UK, ZHC 1/82, House of Commons Testimony of John Matthews, 3 June 1788.

Newton, John, The Journal of a Slave Trader (John Newton), 1750-1754, with Newton's Thoughts upon the African Slave Trade, edited by Bernard Martin and Mark Spurrell (London: Epworth Press, 1962).

Nowak, Bronislaw, “The Slave Rebellion in Sierra Leone in 1785-1796," Hemispheres 3 (1986), 151-169.

Nwokeji, G. Ugo, The Slave Trade and Culture in the Bight of Biafra (Cambridge: Cambridge University Press, 2010).

Owen, Nicholas, Journal of a Slave Dealer: A Living History of the Slave Trade, edited by Eveline Martin (London: Kegan Paul International, 1930).

Peterson, John, Province of Freedom: A History of Sierra Leone, 1787-1870 (London: Faber \& Faber, 1969).

Polhemus, Neal, “A Dialogue with King Agaja: William Snelgrave's 1727 Ardra Diary and the Contours of Dahomian-European Commercial Exchange," History in Africa 43 (2016), 29-62.

Princeton University Libraries, Firestone Memorial Library, Princeton, USA, Manuscripts Division, Special Collections, Captain John Matthews Papers, C1575.

Sanderson, Frank E., “The Liverpool Delegates and Sir William Dolben's Bill," Transactions of the Historic Society of Lancashire and Cheshire 124 (1972), 57-84. 
Schwarz, Suzanne, “A Just and Honourable Commerce': Abolitionist Experimentation in Sierra Leone in the Late Eighteenth and Early Nineteenth Centuries," African Economic History 45-1 (2017), 1-45.

Skemer, Don, "Eyewitness to the Slave Trade," RBSC Manuscripts Division News (7 August 2017), https://blogs.princeton.edu/manuscripts/2017/08/07/eye witness-to-the-african-slave-trade/, (accessed 19 July 2019).

Snelgrave, William, A New Account of Some Parts of Guinea and the Slave Trade (London: James, John, and Paul Knapton, 1734).

Various, "John Tittle's Voyages," Voyages: The Trans-Atlantic Slave Trade Database (2016), https:/ / www.slavevoyages.org/voyage/database, (accessed 3 November 2020), Nos. 91076, 91303, 91422, 91559, 91495, and 91816.

Walker, James W. St. G., The Black Loyalists. The Search for a Promised Land in Nova Scotia and Sierra Leone 1783-1870 (London: Longman, 1976).

Watt, James, Journal of James Watt: Expedition to Timbo, Capital of the Fula Empire in 1794, edited by Bruce L. Mouser (Madison: University of Wisconsin-Madison, 1994). 